\title{
Journal of Management (JOM)
}

Volume 6, Issue 2, March-April 2019, pp. 261-274, Article ID: JOM_06_02_030

Available online at http://www.iaeme.com/JOM/issues.asp?JType=JOM \&VType=6\&IType $=2$

Journal Impact Factor (2019): 5.3165 (Calculated by GISI) www.jifactor.com

ISSN Print: 2347-3940 and ISSN Online: 2347-3959

DOI: 10.34218/JOM.6.2.2019.030

(C) IAEME Publication

\section{CORPORATE SOCIAL RESPONSIBILITY IN INDIA: A REALITY CHECK}

\author{
Sumer Ivan D Cunha \\ Research Scholar, UCCM, Guru Kashi University, Bathinda, India \\ Rajendra Kapil \\ Professor, UCCM, Guru Kashi University, Bathinda, India \\ Mahendra Kumar \\ Dy Dean Research, Guru Kashi University, Bathinda,, India
}

\begin{abstract}
Corporate Social Responsibility (CSR) is a concept of management wherein companies and the corporate integrate social, cultural and environmental aspects in their corporate operations after due diligence with their shareholders / stakeholders. CSR is an important element of development both in urban and rural India, because not only do companies and the corporate draw on communities in urban parts but effect the environment when drawing on resource from rural areas. Many companies have realized this imperative and are motivated to undertake CSR keeping their larger interests in mind. This article traces the theories and models of CSR before analyzing the benefits of CSR to the People, its impact on Company Profits and Planet sustainability. Thereafter it dwells on the evolution of CSR in India, while highlighting the challenges corporate India faces in striving to implement effective CSR more so after the Companies Act 2013 was promulgated.
\end{abstract}

Keywords: Corporate Social Responsibility, Ethical, Management.

Cite this Article: Sumer Ivan D Cunha, Rajendra Kapil and Mahendra Kumar, Corporate Social Responsibility In INDIA: A Reality Check, Journal of Management, 6(2), 2019, pp. 261-274. http://www.iaeme.com/IJM/issues.asp?JType=JOM\&VType=6\&IType=2

\section{INTRODUCTION}

In the past, most of the social issues were assumed to be the responsibility of the State. This role when looked at holistically covered an entire spectrum of activities from social issues impacting communities and societies, to culture and environment sustainability. As populations and aspirations grew, States with limited administrative and financial resources began finding it more and more difficult to start and sustain such activities. The attention shifted to traders and business entities, which over the years had grown and were capable of taking on roles which 
they had not undertaken hither to fore. However, this thought was left to the philanthropic few, while the others reaped the benefits of this indulgence. It is in this that the fundamentals of present day CSR rest and has resulted in a shared public policy, which addresses social issues proportionally between the State and the Corporate.

CSR is a more recent management concept and thus there is dissonance on its definition and its constituents - principles, constructs and dimensions (Crane, McWilliams, Matten, Moon \& Siegal, 2008). As a result there are 42 different definitions accepted globally on CSR (Duhlsrud, 2013), with some suggesting that corporate responsibility is only to a companies' shareholders ie making / increasing profits, (Friedman, 1970), while others arguing that it needs to be more encompassing to include the interests of both the shareholders as well as the stakeholders (Davis, 1973; Skare, \& Golja, 2012; Epstein \& Reje - Buhovac, 2014). Irrespective of this ongoing debate, presently companies and the corporate integrate CSR to balance social, environmental and economic imperatives of stakeholders, while at the same time trying to meet the expectations of the shareholders.

Today, anything that benefits society can be called CSR making the canvas vast, but for CSR to be effective it must be contemporary and relevant to the beneficiaries. Many companies see huge possibilities in CSR as an effective constituent in gaining societal and social acceptance for their operations. The relevance of this is more for companies that are based in remote and rural areas, like those involved in oil and gas exploration and mining companies. By taking on CSR in these remote and rural areas both the small and large communities living in these parts begins to coexist with these communities while growing simultaneously. While corporate and companies address relevant issues in earnest the State cannot absolve itself of their basic responsibility. It is only when the State, society and communities follow ethics that focus on similar objectives that the goals of CSR be achievable.

\section{CONSTRUCT OF CSR}

Corporates' across the world interact with society and thereby impact the lives of people in numerous ways. They establish industry, build infrastructure facilities, develop products and then sell them. As part of this construct they advertently or inadvertently impact both urban and rural regions, because not only do companies and the corporate draw on communities by employing people in urban parts, but directly affect the environment when drawing on natural resource from rural areas. Many companies have realized this and are motivated to undertake CSR with their larger interests in mind. Hence, human capital is nurtured and developed over time as retention of talent is critical to sustained growth of a company, while genuine concern for the environment ensures continual supply of raw material. So while the corporate uses society, people and the environment there is a responsibility and an obligation that it undertakes that protects its interests, besides improving the quality of life of society as a whole (Davis, 1973). Society plays a critical role in the success of any company / organization. Hence, no company / organization can hope to achieve success in the long term by operating in isolation, without meeting its societal responsibilities. These may be solely for business purposes or for emotional reasons. It is on this foundation that the basic construct of CSR lies.

As discussed earlier, perspectives differ, Friedman (1970) stated that, "CSR is beyond the basic purpose of business and violates the responsibility of business to its owners, the stockholders / shareholders", while Goyder (1951) felt that, "industry in the twentieth century can no longer be regarded as private arrangement for enriching shareholders - it has become a joint enterprise in which workers, management, consumers, the local government and trade union officials, all play a part". Kolk and Pinkse (2006), proposed that "stakeholders are any group or individual who can affect or is affected by the achievement of a corporation's purpose. In addition to a company's shareholders, its stakeholders include its employees, the 
communities, suppliers, customers, government and society at large" and Davis and Blomstrom (1975), felt that "it is the obligation of decision makers to take actions that protect and improve the welfare of society as a whole along with their own interest. Protecting and improving are two aspects of social responsibility. 'To protect' implies avoiding negative impact on society, whereas 'to improve' implies creating positive benefits for society". However, Carroll (1991), four tiered pyramid captured all these aspects and best illustrated the definition of CSR by a clear de-confliction of responsibilities, where he stated that "corporate social responsibility involves the conduct of a business so that it is economically profitable, law abiding, ethical and socially supportive". The reason the concept was structured as a pyramid was to bring out the importance of each aspect vis-à-vis the other.

The bottom of the pyramid is based on economic responsibility where in a corporate / organizations must make profits and thereby create wealth. While striving to achieve this, the management has to operate within a set of laws, regulations and rules and this is the legal responsibility of a business. The next layer is ethics - a subset above economic and legal responsibilities and these are actions of businesses expected by society and form the ethical responsibility of a corporate ie some laws are not written but ethically we know what is right and what is wrong. The apex of the pyramid is far more undefined than ethical responsibility and is left to the discretion of the corporate / organization. This aspect is very often termed as discretionary or philanthropic responsibility and is normally voluntary in nature.

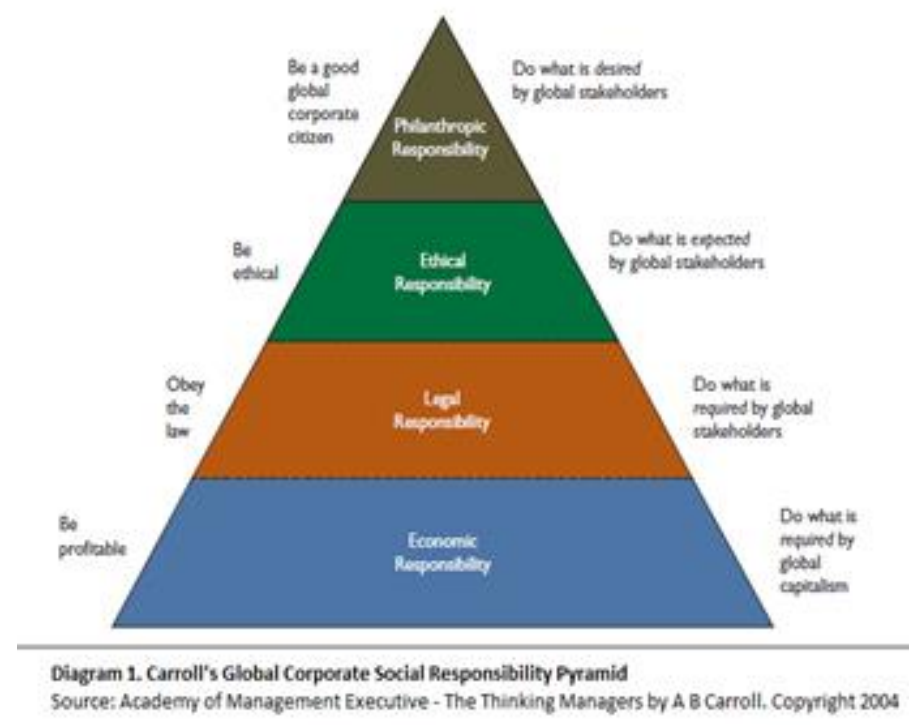

Figure 1 Carroll's Global Corporate Social Responsibility Pyramid.

Presently, across the globe, corporates are judged not only on their performance but also on the above aspects and each of these aspects are quantified to give a social index, the governance index and the environmental index. India is one of the two countries in the world which has legislated on this construct of CSR. Taken holistically, if corporate / organizations realize the importance of CSR and act effectively according to the ethics and the legal framework ( as in India) governing CSR, then the social environment, legal environment and ethical environment will improve, thereby improving the productivity and financial performance of the business.

\section{THEORIES OF CSR}

CSR is best comprehended by understanding the relationship between business and society, because each approach to CSR is defined by a different comprehension. Thus the way a corporate undertakes CSR is based on its comprehension of the concept and manifests in 
different ways. These ways are grouped into four broad theories (Garriga and Mele, 2004) as under:

Instrumental theories. Instrumental theories - wherein maximization of the value of the shareholder is the only criterion for corporate decision making and everything to achieve this criteria is an instrument. Hence, the corporate evaluates specific corporate social activities to achieve economic results and gain competitive advantages by social investments; generating new value creating strategies when exploiting natural resource by acquiring, integrating, modifying and recombining resources; disruptive innovation in services and products adapted to local needs with low-cost of production; and causal marketing by which brand association strengthens due to ethical or social corporate responsibility.

Political theories. Political theories focus on the connections and interactions between society and business. It is based on corporate constitutionalism (Corbett, Angus, \& Spender, 2009) and corporate citizenship (Waddock, 2008). Corporate constitutionalism is bed rocked on the perception that business is a social institution and therefore must use power responsibly, subject to "the social power equation - the social responsibilities of business owners arise from the amount of social power that they have" and "the iron law of responsibility - whoever does not use his social power responsibly will lose it". Corporate citizenship on the other hand is based on three aspects: Corporate Social Performance which emphasizes on results and outcomes; Corporate Social Responsiveness which emphasizes on activity and action; and CSR which emphasizes on accountability and obligation to society.

Integrative theories. Integrative theories realize that a business's growth depends on society. Thus a company should listen to society and then integrate social requirements accordingly by: Management decisions after identifying, evaluating and then generating options to political and social issues; Public Responsibility Principle wherein managerial conduct encompasses public opinion, legal requirements, emerging issues and implementation practices; The Stakeholder Approach (Freeman, 1984) theory.

Ethical theories. Ethical theories arise from ethical responsibilities of business to society ie to do the right thing for a better society. This is achieved by following the Normative Stakeholder theory (Freeman, 1984); Sustainable development "triple bottom line" theory (Elkington, 1994); and most importantly respecting Universal Rights - labor rights, human rights and environment sustainability and survivability.

\subsection{Models of CSR}

An analysis of the theories described above reveal that the approaches in carrying out CSR by corporates differ and even though Carroll gave the basic construct of CSR, various theorists took the construct forward, developing CSR models. Ackerman's model (Ackerman, \& Bauer, 1976) discussed strategies to address issues with a social implication, while the Intersecting Circles Model of CSR (Schwartz, \& Carroll, 2003) reoriented Carroll's earlier hierarchical model by integrating the economic, legal and moral aspects of CSR. 


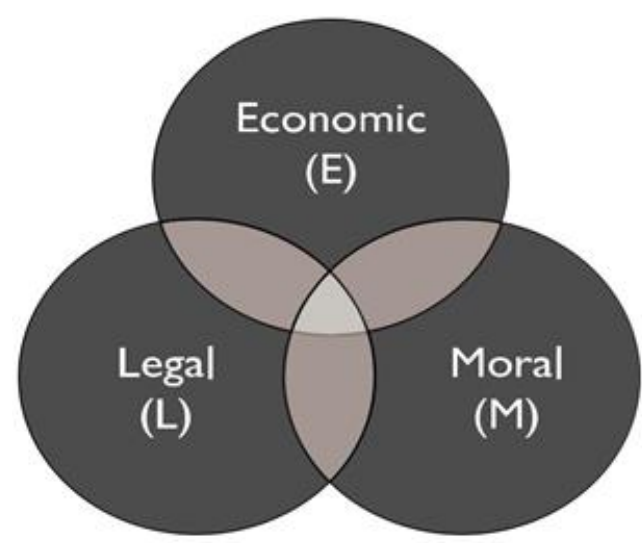

Figure 2. Intersecting Circles Model

Source : Schwartz and Carroll 2003

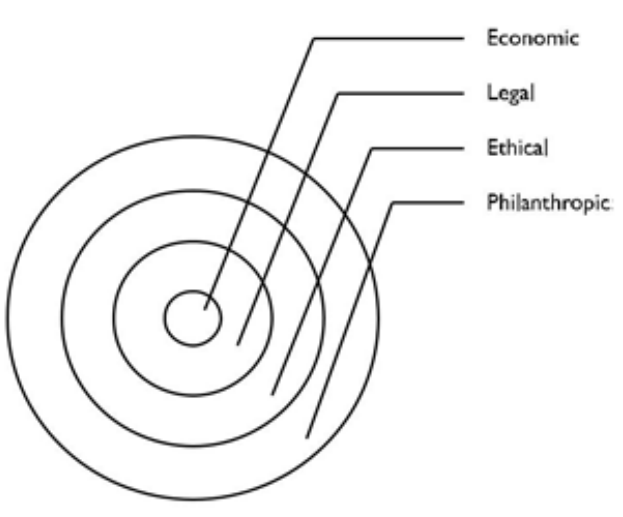

Figure 3. Concentric Circles Model

Source: Committee for Economic Development 1971

The Concentric Circles model (Committee for Economic Development, 1971) had economics forming the core and enveloped by the three rings of ethical, legal and philanthropy. As per this model as one moved from inner to outer ring it represented the internalization of social norms of a corporate and as one moves from outer to inner ring it showed the control society must impose on business activity for greater social progress. Connections with partners, Consistency in behavior and Commitment (encompassing the economic, ethical and legal dimensions) are the 3Cs of the 3C-SR model (Meehan, Meehan, \& Richards, 2006).

India also contributed its thought on CSR by developing two models over the years: the Ethical models of trusteeship envisioned by Mahatma Gandhi; and the Statist model (ASSOCHAM, 2008) based on the mixed economy and socialist framework. However, the models which show a positive CSR - Corporate Financial Performance relationship are the "Stakeholder Theory Model" (Freeman, 1984) and the "Triple bottom Line" (Elkington, 1994) model.

\section{THE RELATIONSHIP BETWEEN STAKEHOLDER THEORY AND CONCEPT OF CSR}

Stakeholder's as per Freeman's (1984) are, “any group or individual who can affect or is affected by the achievement of a corporation purpose". This is a broad definition and leaves the notion of stake and fields unambiguous and all inclusive. (Clarkson, 1995) differentiated between these as 'primary or participant' and 'secondary or non-participant' stakeholders. A 'primary or participant stakeholder' (Metcalfe, 1998), is one without whose continuous participation and cooperation is imperative for the corporate to survive, while the 'nonparticipant or secondary stakeholders' are those who affect or influence, or are affected or influenced by the corporate, but these individuals are not involved in the transactions of the corporate and are not intrinsic to its survival. Further, (Sachs, Maurer, Ruh li, \& Hoffmann, 2006) distinguished the stakeholders categories as benefit receivers / providers and risk bearers / providers.

Hence, whenever one tries to relate the Stakeholder theory and the concept of CSR, the relationship is blurred. Some theorists felt that one is a subset of the other (Cochran, \& Wood, 1991; Mele, 2008) others felt these are competing concepts (Schwartz, \& Carroll, 2008; Brown, \& Forster, 2013), and still others felt they were complementary to each other (Kurucz, Colbert, \& Wheeler, 2008; Jamali, 2008; Russo, \& Perrini, 2010). Viewed critically, the main similarity between Stakeholder theory and CSR is incorporating community interests into corporate operations, while their differences are as under (Table 1): 
Table 1 Comparison between Stake Holder Theory and CSR

\begin{tabular}{|c|c|}
\hline Stake Holder Theory & Concept of CSR \\
\hline $\begin{array}{c}\text { Main responsibility of business is corporate } \\
\text { responsibility; community responsibility is just one } \\
\text { aspect among other corporate responsibilities. }\end{array}$ & $\begin{array}{c}\text { Places corporate social orientation - over all } \\
\text { other corporate responsibilities. }\end{array}$ \\
\hline $\begin{array}{c}\text { Essence of business primarily lies in creating value and } \\
\text { building relationships for stakeholders - employees, } \\
\text { communities, customers, suppliers and financiers. }\end{array}$ & $\begin{array}{c}\text { Oriented toward society only - charity, } \\
\text { environmental efforts, and volunteering and } \\
\text { ethical labor practices. }\end{array}$ \\
\hline $\begin{array}{c}\text { Tends to center its attention on local communities where } \\
\text { the company operates and the company's primary } \\
\text { stakeholders (inner circle) }\end{array}$ & $\begin{array}{c}\text { Tends to extend the social orientation of the } \\
\text { corporate beyond areas of interest, even } \\
\text { globally }\end{array}$ \\
\hline $\begin{array}{c}\text { Believes stakeholders are interdependent, and creating } \\
\text { value for one stakeholder creates value for the others, so } \\
\text { responsibility is multi-directional. }\end{array}$ & $\begin{array}{c}\text { Sees responsibility as uni-directional from the } \\
\text { company to communities / society. Partially to } \\
\text { employees and nothing to customers and } \\
\text { suppliers }\end{array}$ \\
\hline
\end{tabular}

It is evident from the above that the responsibility of corporates to stakeholders is the allencompassing aspect of corporate responsibilities. These include not only the social aspects of corporates to society, but also aspects like sustaining employee's professional growth for career enhancement, partnership building with suppliers and financiers, meeting consumer needs and meeting shareholder aspirations. The latter of all these aspects are an integral part of corporate responsibility and go far beyond the domain of CSR. Thus it is evident that while commonalities exist between the Stakeholder Theory and the concept of CSR in Value Creation, Purpose and Stakeholder Interdependence, CSR is just another subset of the entire spectrum of corporate responsibility as Figure 4.

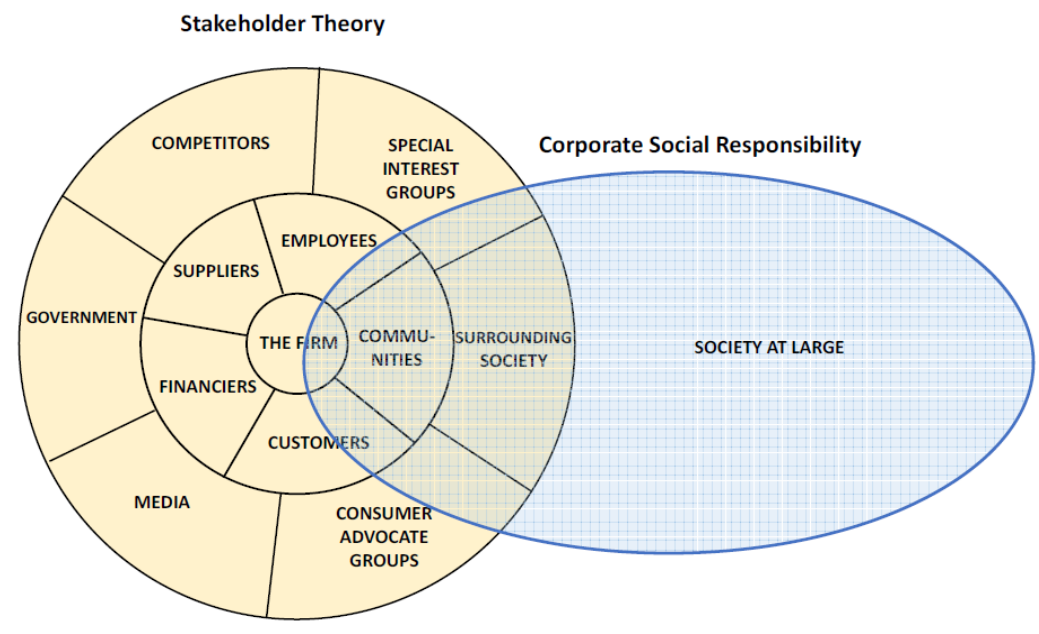

Figure 4. Relation between Stakeholder Theory \& CSR

\section{THE TRIPLE BOTTOM LINE AND CONCEPT OF CSR}

The "Triple Bottom Line" or "The three Ps" is a model introduced by John Elkington. The model is all encompassing covering the People, the Profit the company makes and the Planet and it reflects in a company's performance in the social, financial and environmental index. Since the model revolves around the three Ps the benefits of CSR must also encompass the three Ps. 
People. CSR is a corporate entities contribution to societal development. When a company makes an investment, it effectively communicates to people - its employees, the community and civil society at large. The benefits of CSR to the people are: Employment generation; sponsored housing; community education and social up-liftmen programs; charitable contributions; product quality and safety; employee volunteer activity and programmers.

Profit. CSR may increase companies' profits and thus a large number of companies are actively engaged in CSR. However, linking increased profit directly to abstract variables which are difficult to define is a challenge. Some gain may result as: lower operating costs; improved financial performance; workforce diversity; product safety and minimum liability; greater productivity and quality; access to capital; reduced regulatory oversight; easier to attract fresh talent and retain existing employees; enhanced reputation and brand image; increased sales due to continual customer loyalty.

Planet. Making the planet a better place to live in is a major objective and outcome of Environmental CSR. This is because it aims to reduce the harmful effects from business' processes, besides providing options for cost savings by: enhanced material recyclability; focused exploitation of renewable resource and emission control; better product functionality and durability; integration of environmental management techniques and tools into business strategy.

\section{EVOLUTION OF CSR IN INDIA}

Over the centuries social responsibility and religion in India have been intrinsically intertwined. This social responsibility was called "Loksamaghrah" in the Bhagavad Gita; in Vedic mythology business was part of society and it was "Sarva loka litam", which meant the wellbeing of all stakeholders; in the Arthashastra - Kautilya spoke of it as "Praja sukhe sukham", which meant that the better off / well to do in society had a responsibility towards helping those in need; some sects of Hinduism suggested "Dharmada", wherein the seller invariably charged a small amount from the buyer which he then used for building temples besides providing shelter and food for the poor; Islam had a proclaimed law called "Zakaat", which involved sharing a part of an individual's earnings with the under privileged; Sikhism followed something called "Daashaant"; and the Christians give their "Tithes", to the temple / church. The evolution of CSR in India can be traced from these religious traditions and can be broken down into the following phases.

Phase I (1850 - 1915). The first phase of social responsibility in India is known for its philanthropic nature and charity. The efforts were largely influenced by family traditions, values, religion and culture. This manifested in the spiritual growth of the people, communities and society by the construction of religious institutions and temples and was supported by feeding the hungry and poor in case of natural calamities like drought and famine. In the turn of the $19^{\text {th }}$ Century there was lot of religious and charity work done through charitable foundations for community development.

Phase II (1915 - 1960). With the advent of the industrial revolution the business houses of Tata, Bajaj, Godrej, and Birla etc flourished and they extended the concept of social responsibility by setting up educational and health oriented institutions. The Independence movement dominated by Mahatma Gandhi gave social responsibility a course correction, where in big industrialists were coerced into sharing their wealth for the benefit of the poor and marginalized. Under this ethical phase evolved the concept of trusteeship in India which helped both social and economic growth in the country. According to Mahatma Gandhi, industries and companies were "temples of modern India" and their contribution was intrinsic to every field of socio-economic development - thus corporate philanthropy became more institutionalized. The outcome was social reformation in empowerment of women, rural development and 
education including scholarships for children going aboard for studies and establishment of centers of scientific and technical research, cancer research and study centers for social sciences and up-liftmen.

Phase III (1950 - 1990). Socialism or the statistic model dominated this phase and the emergence of the Public Sector Undertakings for better job creation and wealth distribution was the outcome. The Public Sector Undertakings were largely unsuccessful in effective social responsibility due to poor profitability, resulting in the expectations shifting from the public sector to the private sector. However the license raj, high taxes and the quota system controlled their activities besides bringing in mal practices. The Companies Act of 1956 could not stem the problems and it was only in 1965, after academicians, businessmen and politicians conducted a reality check across India on social responsibility that the emphasis was realigned to social transparency and accountability.

Phase IV (1990 - 2013). In this liberal phase CSR became an integral part of a sustained business strategy. The "Stakeholder Approach" and "Triple Bottom Line Approach of Profit, Planet and People" ensured that CSR became more broad bases and holistic. This was predominately due to the country's economic boom led by opening up of the Indian economy and the wave of privatization, liberalization and globalization. As profits improved options for companies and corporate houses to increase their contribution towards social responsibility rose, but the contribution and social responsibility was determined by corporate whim.

Phase V (2013 onwards). The Companies Act 2013 replaced the Companies Act 1956 and removed this ambiguity. The Act applies to all companies and has the following relevant provisions (in a financial year) with respect to CSR applicability:

- "The Company should have a net worth greater than 500 crore Rupees, an annual turnover greater than 1,000 crore Rupees and a net profit greater than 5 crore Rupees.

- The CSR corpus must be 2 percent of the average net profit of previous three years.

- Pooling or collaborating of resources between companies which undertake CSR activities also qualifies for computing CSR spending.

- Companies under the provision of Section 135 (1) of the Act must report in the standard format their CSR initiatives both on the company's website and in the director's report.

- Reasons of inability in spending the $2 \%$ allocation of average net profit must be covered in the annual board report.

- Schedule VII of the Act stipulates the areas of CSR activity which are:

- Eradicating extreme poverty and hunger;

- Promotion of education;

- Promoting gender equality and empowering women;

- Reducing child / infant mortality and improving maternal health;

- Combating HIV, AIDS, malaria, polio and other diseases;

- Ensuring environmental survivability and sustainability;

- Employment enhancing vocational skills;

- For the Benefit of the Indian Armed Forces veterans, war widows, their dependents and Special children;

- Contribution to the Central or State Relief Fund for socio-economic development and relief and for welfare of Scheduled Castes, Scheduled Tribes, women and minorities." 
- This Act was amended in December 2018 and is now called the Companies (Amendment) Act 2018.

\section{OUTCOME OF THE COMPANIES ACT 2013}

On the Private Sector. The shifting of a company's CSR responsibility paradigm from a shareholder to a stakeholder centric approach has induced a radical transformation in the implementation of CSR at ground zero. This has resulted in company's innovating to increase efficiency, effectiveness and accountability. The focus today has moved away from charitable financial aid and scholarships to services and products which are people-centric with the participation of local community at all levels. Most efforts are customized to the meet specific requirements of the target group, suitably backed up not only by finances, but also by manpower, expertise and services, for the all-encompassing implementation of the schemes.

On the Public Sector. The Public Sector Undertakings operations are more in back end infrastructure like coal, petroleum, mining, steel, aviation etc and hence their CSR is more central in the development of backward regions of India. Bharat Heavy Electronics and Indian Airlines have also formed an integral part of disaster management and relief efforts and overseas evacuation. Their CSR contribution is also higher at $3 \%$ of profits.

Increased Customer Interest and Pressure. There is an increased customer interest among those aware, on the ethics companies use to make their profits and gain market share, more so in the consumer space. This awareness is gradually impacting the decisions of customers especially when they have to make a choice. As awareness grows in India, which is evident from the number of Indians going to various consumer forums for redress of their grievances, their future procurement decisions are likely to be altered based on the companies perceived social performance.

Greater Disclosure Demand. There is a growing demand by all stakeholders - employees, customers, suppliers, communities, investors, and activist organizations for companies to make greater disclosures on CSR activity.

On CSR Spending. The average net profit of 1000 companies surveyed over the past three years was Rs 4.79 lakh crore (in 2015-16 it was Rs 4.59 lakh crore). As per the Act of 2013 for CSR, the amount required to be spent by companies meeting the Act criteria in 2017-18 was to be Rs 9,543.51 crore (2016-17: Rs 9,275 crore). Education including Skill Development saw the maximum spend of 35\% (Rs 3121 crore), followed by Poverty Alleviation \& Healthcare (Swachh Bharat) at 27\% (Rs 2385 crore), Environment sustainability 11\% (Rs 911 crores up $31 \%$ ) and Swachh Bharat related efforts got $7.3 \%$ (693 crore). The Armed Forces Welfare for Veterans, War Widows collectively got a meager amount of Rs 16 crore in 2015-16, Rs 32 crore in 2016-17 and Rs 9 crore in 2017-18 (NOGBOX Data).

Table 2 Authors Compilation Based on CSR Outlook Report by NGOBOX

\begin{tabular}{|l|l|c|c|c|}
\hline No & \multicolumn{1}{|c|}{ ITEM } & $\begin{array}{c}\text { CSR DETAILS } \\
\text { FY 2015-16 }\end{array}$ & $\begin{array}{c}\text { CSR DETAILS } \\
\text { FY 2016-17 }\end{array}$ & $\begin{array}{c}\text { CSR DETAILS } \\
\mathbf{2 0 1 7 - 1 8}\end{array}$ \\
\hline 1 & Actual CSR & 7143 crore & 9275 crore & 9543.51 crore \\
\hline 2 & Prescribed CSR & 6578 crore & 8446 crore & 8875.93 crore \\
\hline 3 & $\begin{array}{l}\text { Change in CSR } \\
\text { Compliance }\end{array}$ & $+13 \%$ & $-1 \%$ & $+2 \%$ \\
\hline \multirow{3}{*}{4} & Distribution & & & $35 \%$ \\
\cline { 2 - 5 } & Education & $31 \%$ & $35 \%$ & $27 \%$ \\
\cline { 2 - 5 } & Skill Development & & $25 \%$ & \\
\cline { 2 - 5 } & Healthcare & $33 \%$ & 2 & \\
\hline
\end{tabular}




\begin{tabular}{|c|c|c|c|c|}
\hline No & ITEM & $\begin{array}{l}\text { CSR DETAILS } \\
\text { FY 2015-16 }\end{array}$ & $\begin{array}{l}\text { CSR DETAILS } \\
\text { FY 2016-17 }\end{array}$ & $\begin{array}{c}\text { CSR DETAILS } \\
2017-18 \\
\end{array}$ \\
\hline & $\begin{array}{l}\text { Poverty Alleviation \& } \\
\text { WASH }\end{array}$ & & & \\
\hline & $\begin{array}{l}\text { Gender Equality \& } \\
\text { Women Empowerment }\end{array}$ & $3 \%$ & $2 \%$ & $2 \%$ \\
\hline & Heritage \& Art & $2 \%$ & $2 \%$ & $3 \%$ \\
\hline & $\begin{array}{l}\text { Environment } \\
\text { Sustainability }\end{array}$ & $8 \%$ & $10 \%$ & $11 \%$ \\
\hline & Sports & $2 \%$ & $2 \%$ & $2 \%$ \\
\hline & Rural Development & $12 \%$ & $13 \%$ & $11 \%$ \\
\hline & PM Relief Fund & $2 \%$ & - & $3 \%$ \\
\hline & Others & $7 \%$ & $11 \%$ & $6 \%$ \\
\hline
\end{tabular}

Competitive Hiring Markets. With the clear refinement of CSR in improvement of the employees working conditions, companies have no option but to improve work culture and environment, if they want to hire the best talent in the market or retain existing efficient employees. Presently, in addition to pay packages and benefits employees are identifying entities whose operating practices and philosophies match their own thought and principles.

Supplier Relations. Very often, the code of ethics or conduct is deliberately not extended to suppliers by companies, so that the shortfalls of the policies and practices of these suppliers do not affect the reputation of the mother company. As stakeholders and shareholders take greater interest in business aspects, many companies, more so the consumers are taking effective steps to ensure that all the suppliers or sub entities conduct themselves in a socially acceptable manner. The famous Maggi noodle case of Nestle is a effective example to prove this point.

\section{POTENTIAL OF CSR}

On Brand Equity. The above discussion has clearly brought out that corporates have a responsibility towards society and CSR is one of the instruments to meet this obligation. However, effective CSR has the potential of benefiting corporates as well, by brand building. A brand helps conjure up a vision of a corporates service or product in the mind the consumer / customers mind and this is achieved by delivering on promises and creating a feel good factor. The promise can be towards aspirational fulfillment, experimental enrichment, societal improvement or functional satisfaction (Kapferer, 2004 and Keller, 2009). The greater the familiarity with the brand the easier to build brand equity for the company and CSR provides a platform. The essentials of Brand Equity are always from the customers point of view since they manifest in brand awareness - the brand preference strength in an individual's mind; brand loyalty - which shows the intension to repurchase the same item; brand image - impression of the product; brand association - emotional linkage that makes the brand enhance an individual's self-image; and perceived quality of the product.

On Profitability. Whenever a corporate undertakes CSR for societal upliftment (including disaster reconstruction) and environmental protection its brand equity improves and more and more consumers want to associate with the brand. When this happens each consumer is willing to pay a higher price for the brand in comparison to an identical product which may be cheaper from another company. This implies that a consumer pays higher amounts for company brands which have a higher brand equity level. All these aspects translate into greater sales volumes which in effect contributes to the increased profitability of the company. Thus positive brand equity helps increases profit margin per consumer, because it provides an avenue for a company to charge a higher price for a product or service than its competitors, even though the input 
costs for both may be approximately the same, while negative brand equity would have just the opposite impact on sales, consumer retention and profitability.

\section{CHALLENGES IMPACTING CSR INITIATIVES}

Legislation has changed the dynamics of CSR implementation across India with about 10,000 companies, both public sector and private including multinational companies being covered by the Companies Act 2013. Effective CSR necessitates detailed planning of an achievable end state and the target group in mind. If local issues of all stakeholders are not part of the planning process, then most often the designing is flawed and the implementation mired in delays. A survey recently of implementing organizations conducted across India by the Times Group elicited complex responses on the various challenges in different parts of India being faced by CSR initiatives. Some of these are covered in the succeeding paragraphs.

Community Level Participation in CSR activities. The various CSR initiatives for some reason have not generated the required enthusiasm either in the local community or within Panchayats to participate and contribute in the CSR plans envisaged by companies. This is possibly because: there is limited or zero knowledge about CSR initiatives within the local community's or within the Panchayats; there is no serious effort on the part of companies to spread awareness about their CSR activities; no past precedence's exist which can instill confidence or display clear intent to the local population or communities about such initiatives; a lack of communication exists between the company's planning team, its process and the grassroots community.

Building Local Capacities.A large number of local non-governmental organizations have taken up the task of implementing CSR on behalf of companies. There is a need to build the capabilities and the capacities of the people working in these non-governmental organizations so that the thought behind initiatives planned by companies are understood and effectively executed. If local capacities are built up then the scope of each CSR initiative can be broadened and subsequently scaled up in every successive year.

Issues of transparency.Understanding requirements, joint planning and successful implementation of CSR projects are the foundation on which trust is built between local communities and companies. However, most companies feel that once CSR funds are allocated / released, the local implementing agency is averse to providing programme information, reports both with regard to project progress and fund utilizations, besides not wanting to audit their accounts. Hence, companies do not gain the leverage they seek to achieve through their CSR contribution.

Non-availability of Competent NGO's. There is an extreme dearth of availability of wellorganized NGO's in rural and remote areas of India that can identify and assess the real needs of a community and then work in tandem with companies and the corporate to ensure time bound implementation of CSR activities. Thus capacity and capability building of the executing agency to execute development projects at local levels is imperative if true benefit has to accrue to the target group.

Media Role. Most companies contributing to CSR would take great pride if their initiatives are lauded by the media. This would not only help them in promoting the efforts of their company in their various CSR initiatives, but would also enable them in leveraging the benefits of their contribution towards their brand equity. Realizing this large number of nongovernmental organizations shift the CSR objective from actual projects, to a branding and visibility exercise. Hence, media must be used constructively when depicting CSR initiatives.

Limited Perception of CSR Initiatives. Government agencies and NGO's usually possess a myopic view towards companies CSR initiatives, often classifying or defining them as being more donor driven to meet regulatory requirements than local in thought and approach. As a 
result, a number of companies find it difficult to decide whether they should directly participate in such activities in the short, medium and long term or just outsource the responsibility to an NGO.

Non-availability of Clear CSR Guidelines. In the absence of any Indian guidelines the Global Reporting Initiative guidelines are being used in order to have some standardization on the CSR reporting. The version was upgraded to version 3.0 ( G3) in 2006 and it creates a framework for reporting voluntarily on the impact CSR has had on the people (social), profit (economic) and planet (environment). The objective is to enhance credibility and comparability of CSR reporting worldwide.

Lack of Consensus on Implementing CSR Issues: There is very often a complete lack of consensus amongst local agencies regarding CSR projects. This lack of consensus has often resulted in duplication of activities by corporate houses in the same area. This has largely resulted in a competitive spirit between local implementing agencies rather than in the concept of building collaborative approaches on important issues. This factor has limited a company's ability to undertake impact assessment of their initiatives from time to time.

\section{RECOMMENDATIONS}

CSR has huge potential in India but time bound aspects to mainstream it for effective deliverables need to be initiated. These steps once in place will ensure CSR is on firmer ground. Some of the recommendations for consideration by all stakeholders which is imperative for effective operationalization and deepening CSR in the core business of companies and which will enable building collaborative relationships and strengthen effective networks are:

Awareness. The general public must be made aware of CSR initiatives being undertaken in their areas. This can be done either by the stakeholders or by effective exploitation of the media and can be used to show change dynamics achieved by CSR initiatives by a company. This will change the attitude and approach of the public towards CSR initiatives being funded by business houses, while simultaneously triggering additional initiatives by the company.

Social Justice Agenda. As awareness spreads and companies get the desired publicity and appreciation more corporate will be motivated to undertake CSR initiatives to address issues like access to health care, education and livelihood / skilling opportunities. Thus, the social justice agenda of pursued equality would be strived for and become more meaningfully.

Small and Medium Enterprises (SMEs). An assessment of current CSR activities clearly brings out that mostly large and medium business houses, in specific geographical areas undertake or are involved in CSR activities through their foundations, while SMEs with a far greater geographical spread and wider reach make their allocation under the Act and remit this to National / State Relief Funds. This method obviates their direct indulgence in any CSR initiatives. If these SMEs pool their limited resources the benefits would be far more tangible to society, than if they do so in their individual capacities or by just undertaking remittances.

Pooling of Resources. A large number of beneficial CSR initiatives have a wider scope but get limited due to paucity of funds. Hence the entire benefits which must accrue in a time frame, get restricted due to staggered year by year implementation. If NGOs and corporate houses pool their resources and build synergies, projects can be scaled up with newer innovations to implement superior CSR practices. The outreach would be far higher - more beneficiaries and increase the impact of initiatives on the day to day life of the common man.

Rural Centric CSR. A large number of CSR programs and initiatives are undertaken in rural localities and areas. This certainly benefits the underprivileged in rural India, who are deprived of basic facilities and services, but most of the impact of such initiatives / projects does not reach the poor and needy in rural areas with limited access and no industry and the 
urban poor. Hence, while continuing to focus on rural centric CSR, companies should actively intervene in extremely backward / underdeveloped naxal areas and urban India in the fields of the girl child education, child labor and sanitation and health, even though it may not translate into increased visibility.

Recognition. Presently all CSR business houses are painted with the same brush irrespective of the effectiveness of their CSR projects / initiatives. The Government of India must consider recognizing and rewarding corporate houses and their NGO partners where results to the underprivileged and poor are quantifiable and visible. The Government can also consider incentives to these business houses to strengthen their good work by fiscal incentives including matching tax breaks and project grants for developmental and social projects. This will enhance competition and be a catalyst in enhancing voluntary participation of many more business houses or entities in CSR activities.

Mandated Business School Syllabus. Presently most students taking commerce or business studies from Class XI onwards are not exposed to the huge possibilities and opportunities CSR provides in developmental issues and societal up-liftment. Impressionable and inquisitive minds will be forced to think on these lines if curriculums are improved both at the junior college and university levels to include CSR as a discipline or subject. This will enable students understand the role of CSR and how is acts as an enabler in helping business houses strike a balance between societal concerns and their business, besides making them understand future challenges and develop innovative solutions to meet the requirements of the poor and needy.

Accreditation System. Today there are about 300 companies in India which are directly involved in executing CSR projects across India. Very often the projects undertaken by them are decided by their core competence and comfort levels. However, it is important that this process is audited by an accreditation system through an independent organization. This will enable institutionalizing and mainstreaming CSR in the business framework of companies and ensure a 'bottom-up' approach for societal and development projects / initiatives in the country.

\section{CONCLUSION}

The concept of CSR is now an integral part of the global and Indian business matrix. However, to jettison the concept from theory to deliverables the many challenges elucidated need to be addressed. A major challenge facing corporate India is the need for reliable and verifiable indicators of progress in the CSR field, along with the simple and effective dissemination of CSR strategies. Dialogue and transparency can help make a business effort in CSR appear more dependable and trustworthy, besides pushing up the standards of the various other organizations concurrently. As realizations dawn, all the stakeholders will push for effective CSR efforts as these efforts will manifest in a win-win for all. As businesses grow, communities gain and as communities gain, societies flourish and as societies flourish, businesses gain, making the cycle cumulative resulting in a collaborative growth of our Nation State - India.

\section{REFERENCES}

[1] Ackerman, R., \& Bauer, R, Corporate Social Responsiveness: The Modern Dilemma. Reston, VA: Reston Publishing Company, 1976

[2] Brown, J., \& Forster, W, CSR and Stakeholder Theory: A Tale of Adam Smith. Journal of Business Ethics, 112 (2), 2013, p.301-312.

[3] Carroll, A. B., A Three-Dimensional Model of Corporate Performance. Academy of Management Review, 4(4), 1979, p. 497- 505.

[4] Carroll, A. B, the Pyramid of Corporate Social Responsibility: Toward the Moral Management of Organizational Stakeholders. Business Horizons, 34, 1991, p. 39-48. 
[5] Cochran, P., \& Wood, R, Corporate Social Responsibility and Financial Performance. Academy of Management Journal, 27, 1984, p. 42-56.

[6] Committee for Economic Development, Social Responsibilities of Business Corporations. New York: Committee for Economic Development, 1971

[7] Corbett, Angus, \& Spender, P, Corporate Constitutionalism. Sydney Law Review, 31(1), 2009

[8] Dahlsrud, A, How Corporate Social Responsibility is defined: An analysis of 42 definitions. Corporate Social Responsibility and Environmental Management, 15, 2008, p. 1-13.

[9] Elkington, J, Cannibals with Forks: The Triple Bottom Line of 21st Century Business, 1997

[10] Freeman, R. E, Strategic Management: A Stakeholder Approach. Massachusetts: Pitman Publishing, 1984

[11] Friedman, M, The Social Responsibility of Business is to increase its Profits. The New York Times Magazine, 1970

[12] Garriga, E., \& Mele, D, Corporate Social Responsibility Theories: Mapping the Territory. Journal of Business Ethics, 53 (2), 2004, p. 51-71.

[13] Goyder, G, Understanding Social Responsibility. The Institutional Framework of Industry, 1951

[14] Keller, K, Managing the Growth Tradeoff: Challenges and Opportunities in Luxury Branding. Journal of Brand Management, 16 (5), 2009, p. 290-301.

[15] Kurucz, E., Colbert, D., \& Wheeler, D, The Business Case for Corporate Social Responsibility. Oxford University Press, 2008, p.83-112.

[16] Metcalfe, C., The Stakeholder Corporation, Business Ethics. A European Review, 1, 1998, p. 30-36.

[17] Schwartz, M. S., \& Carroll, A. B, Corporate Social Responsibility: A Three-domain Approach. Business Ethics Quarterly, 13(4), 2003, p. 503-530.

[18] Skare, M., \& Golja,T, The Impact of Government CSR supporting Policies on Economic growth. Journal of Policy Modeling, 36, 2014, p. 562-577.

[19] Waddock, S, Creating Corporate Accountability: Foundational Principles to Make Corporate Citizenship Real. Journal of Business Ethics, 50(4), 2004, p.313-327. 